NOTE

\title{
White spot syndrome virus (WSSV) detected by $P C R$ in rotifers and rotifer resting eggs from shrimp pond sediments
}

\author{
Dong-Chun Yan ${ }^{1}$, Shuang-Lin Dong ${ }^{1, *}$, Jie Huang ${ }^{2}$, Xiao-Ming Yu ${ }^{1}$, Min-Yi Feng ${ }^{1}$, \\ Xiang-Yi Liu ${ }^{1}$
}

\begin{abstract}
${ }^{1}$ Mariculture Research Laboratory, Fisheries College, Ocean University of China, Qingdao 266003, PR China
${ }^{2}$ Yellow Sea Fisheries Research Institute, Chinese Academy of Fishery Sciences, Qingdao 266071, PR China
\end{abstract}

\begin{abstract}
White spot syndrome virus (WSSV) was detected by PCR-dot blot hybridization in rotifer resting eggs from shrimp Penaeus chinensis culture-pond sediments. It was also detected in rotifers hatched from those eggs. Surface disinfection before analysis indicated that WSSV was probably present within the resting eggs. Results suggested that rotifer resting eggs may be an overwintering reservoir for WSSV in shrimp ponds.
\end{abstract}

KEY WORDS: Rotifer resting eggs · White spot syndrome virus $\cdot$ Transmission route

\section{INTRODUCTION}

Epizootics attributed to white spot syndrome virus (WSSV) first occurred in shrimp farms in East Asia in 1992-1993 (Inouye et al. 1994, Nakono et al. 1994, Takahashi et al. 1994, Chou et al. 1995, Huang et al. 1995a,b, Wang et al. 1995, Wongteerasupaya et al. 1995, Lo et al. 1996a). They spread rapidly and had reached as far as the western hemisphere by 1995 (Lightner 1996, 1999, Jory \& Dixon 1999). Since WSSV can cause mortalities of $80 \%$ or more within 3 to $10 \mathrm{~d}$ in cultivated penaeid shrimp stocks (Huang et al. 1995a,b, Lightner 1996), it is currently the main disease threatening sustainable shrimp farming.

The morphology and structure of WSSV are well known, and several techniques including histopathology, serology and DNA technology (e.g. PCR and DNA probes) have been developed for its detection. During the past $10 \mathrm{yr}$, these techniques have been widely used to study modes of WSSV transmission, and several routes of infection have been found. These include not only carrier shrimp larvae, other crustaceans (e.g crabs) and plankton in and around culture ponds, but also bird feces (Huang et al. 1995a,b, Lo et al. 1996b, Chang et al. 1998, Rajendran et al. 1999, Wang et al. 1999). Despite this knowledge and the implementation of measures to reduce transmission (Wang et al. 1998, 1999), the occurrence of WSSV outbreaks is still very high in mainland China, especially in more northernly regions. This may be due to the fact that some major transmission routes have not yet been discovered.

Huang et al. $(1995 a, b)$ reported that some zooplankton, such as copepods, were positive for WSSV by serological detection and might therefore be able to transmit the virus in shrimp ponds. Nowadays, shrimp farmers usually disinfect the pond water before stocking or before addition during the culture process to avoid this problem. In the spring of 2002 at Rushan Shrimp Farm, Shandong, PR China, we disinfected water in 3 culture ponds with high-concentration (100 ppm) bleaching powder before stocking shrimp. In addition, the 3 ponds were enclosed by fences to 
prevent crab entry. Despite these measures, we found that new zooplankton that appeared within $20 \mathrm{~d}$ postdisinfection (i.e. $1 \mathrm{~d}$ before stocking) were positive for WSSV by PCR. Therefore, we hypothesized that some zooplankton resting eggs deposited in the pond sediments may have been a WSSV reservoir with the potential capability of transmitting WSSV through the food web to farmed shrimp. In this study, we examined the possibility that rotifer resting eggs in pond sediments and rotifers hatched from them might be WSSV reservoirs.

\section{MATERIALS AND METHODS}

Sediment collection. Sediments $(1 \mathrm{~cm}$ surface layer of pond mud) were collected from 3 ponds in Rushan Shrimp Farm and spooned into plastic bottles to be brought back to the laboratory for analysis.

Resting egg separation and hatching. Eggs in the sediments were separated according to the method of Marcus (1989), with slight modification. Briefly, 1 spoonful of mud (approximately $10 \mathrm{ml}$ ) was added to a $250 \mathrm{ml}$ beaker containing $200 \mathrm{ml}$ sterilized seawater and sonicated for $30 \mathrm{~s}$ at 200 to $400 \mathrm{~W}$ using a JY92-II sonifier cell disruptor. The mixture was then filtered through a $52 \mu \mathrm{m}$ plankton screen and the captured material was resuspended in a solution of refined sugar (sugar:distilled water $=1: 1 \mathrm{w} / \mathrm{v}$ ) and centrifuged for $5 \mathrm{~min}$ at $4000 \times \mathrm{g}$. The material remaining in suspension was again filtered through a $52 \mu \mathrm{m}$ plankton screen and washed thoroughly with seawater before transfer to a dish containing seawater for microscopic observation. Rotifer resting eggs (10) were picked from the dish under a microscope using a capillary tube and placed in a $100 \mathrm{ml}$ beaker with sterilized seawater. Hatching was carried out in an illuminated incubator at $25^{\circ} \mathrm{C}$ with a $12 \mathrm{~h}$ light: $12 \mathrm{~h}$ darkness regime.

DNA extraction. DNA extraction of rotifer resting eggs and hatched rotifers was carried out according to the method of Wang et al. (2000). Materials were stored in SEMP-Tris and extracted by boiling ethanol precipitation. Dried DNA was dissolved with Trisethylenediaminetetraacetic acid (TE) buffer.

Detection methods. PCR (polymerase chain reaction), DNA probe dot blot hybridization and PCR-inner DNA probe dot blot hybridization were used as detection procedures. Briefly, 2 pairs of primers were designed by Primer Premier 5.0 program (PREMIER Biosoft International, Silicon Valley, USA) based on the whole WSSV DNA sequence (F. Yang et al. 2001). The first primer pair was 5'-CCA AGA CAT ACT AGC GGA TA-3' and 5'-GAC GAC CCT GAC AGA ATT AC-3' with a product fragment of 235 bp (256481-256715 bp of AF332093 in GenBank). This pair was used for PCR amplification from DNA templates. The second primer pair was 5'-GGG AAG TGA ATA CGC AGT GA-3' and 5'-GTT CTA GGG CAA ACA ATG GC-3', which amplified a 101 bp fragment (256529-256629 bp of AF332093 in GenBank) within the sequence of the first primer pair product. This primer pair was used to prepare a DIG (digoxigenin) labeled DNA probe using DIG Labeling Mix from Roche according to the manufacturer's instructions. The electrophoresis detection limit of PCR using the first primer pair was approximately 1 pg (about 3000 copies) of WSSV DNA, but this could be improved to $10 \mathrm{fg}$ (about 30 copies) WSSV DNA by dot blot hybridization with the PCR product using the probe described above. In contrast, direct dot blot hybridization could detect only $1 \mathrm{ng}$ (about $3 \times 10^{6}$ copies) or more of WSSV DNA (Yan et al. 2004).

Surface disinfection of resting eggs. In order to determine whether WSSV was situated within the resting eggs, they were treated for 30 min with Manful King chlorine disinfectant to destroy surface WSSV DNA (B. Yang et al. 2001). They were subsequently washed thoroughly with sterilized seawater before DNA extraction.

\section{RESULTS}

\section{Rotifer resting eggs and hatched rotifers}

Eggs of 5 types, with different shapes and sizes, were separated from Rushan shrimp ponds. At present, only 1 type of rotifer resting egg has been successfully hatched in large quantities; we still do not know what organism produced the 4 other types of unhatched eggs seen. The successfully hatched rotifer resting egg were yellow-brown, 90-110 $\mu \mathrm{m}$ in length and 70-90 $\mu \mathrm{m}$ in width (Fig. 1). This type of egg was rare in

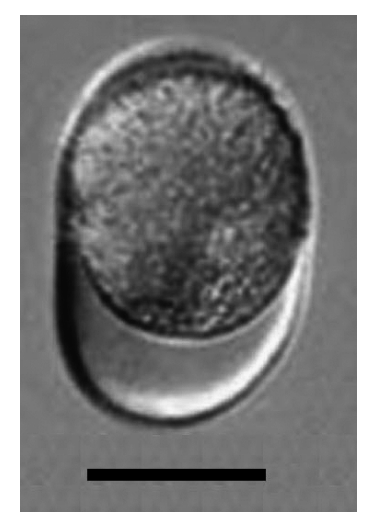

Fig. 1. Rotifer resting eggs separated from Rushan sediment. Scale bar $=50 \mu \mathrm{m}$ 


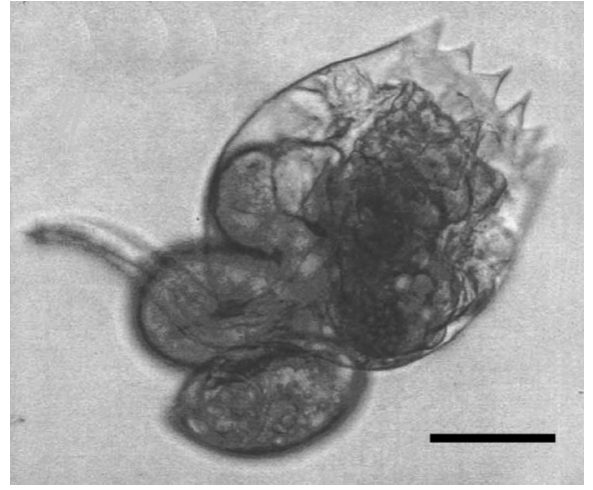

Fig. 2. Rotifer hatched from the resting egg shown in Fig. 1 and identified as Brachionus urceus. Scale bar $=50 \mu \mathrm{m}$

June 2002, but abundant in October 2002 and January 2003. Rotifers hatched from these resting eggs (Fig. 2) were identified as Brachionus urceus.

\section{WSSV detection in rotifer resting eggs and rotifers}

Only 1 rotifer resting egg sample containing 3 eggs was WSSV-positive (Lane 3 in Fig. 3) by PCR-electrophoresis. The other 2 resting egg samples (2 eggs and 1 egg) and all rotifer samples (containing 1 to 3 rotifers) were negative. However, PCR-dot blot hybridization with the same PCR products revealed $2 \mathrm{WSSV}$ positive rotifer resting egg samples (A3, B2 in Fig. 4), 4 WSSV-positive rotifer samples (B4, B5, B7, B8 in Fig. 4) and 3 other WSSV-positive egg samples (A4, A7, A10 in Fig. 4). In contrast, 2 samples of seawater used for separating sediment eggs and for washing rotifers (A1, A2 in Fig. 4) were both WSSV-negative. None of the samples gave WSSV-positive results by direct dot blot hybridization without PCR (C1-D9 in Fig. 4).

\section{Detection of WSSV in resting eggs after surface disinfection}

Testing of rotifer resting egg samples by PCR-dot blot hybridization after Manful King ${ }^{\mathrm{TM}}$ disinfection revealed that 8 out of 11 were WSSV-positive (A1-A4, B1-B3, and B5 in Fig. 5); 5 samples of other eggs (C1-C3, C6, and D3 in Fig. 5) were also WSSV-positive by this test. Seawater used to separate and wash the eggs was WSSV-negative (B6 in Fig. 5).

\section{DISCUSSION}

The fact that WSSV could be detected in rotifer resting eggs and rotifer samples by PCR-dot blot hybridization indicated that WSSV was present in trace amounts and that sensitive methods were necessary to detect it. We tested a total number 16 resting eggs in the surface disinfection test ( 8 positive samples including 11 eggs and 3 negative samples including 5 eggs). Since some samples were pooled, we do not know whether 1 or more eggs were positive for the pooled samples, but at least 1 of the pooled eggs can be considered positive. Thus, we have a total of 8 positive test results from 16 eggs. Assuming that our samples were a random representation of the whole pond sediments and that the sediments contained in excess of 100000 rotifer eggs, we used veterinary sampling software (Cameron 2002) to make a rough estimate of the prevalence of WSSV in the eggs. A result of 8 positive tests from a total of 16 would indicate a prevalence of

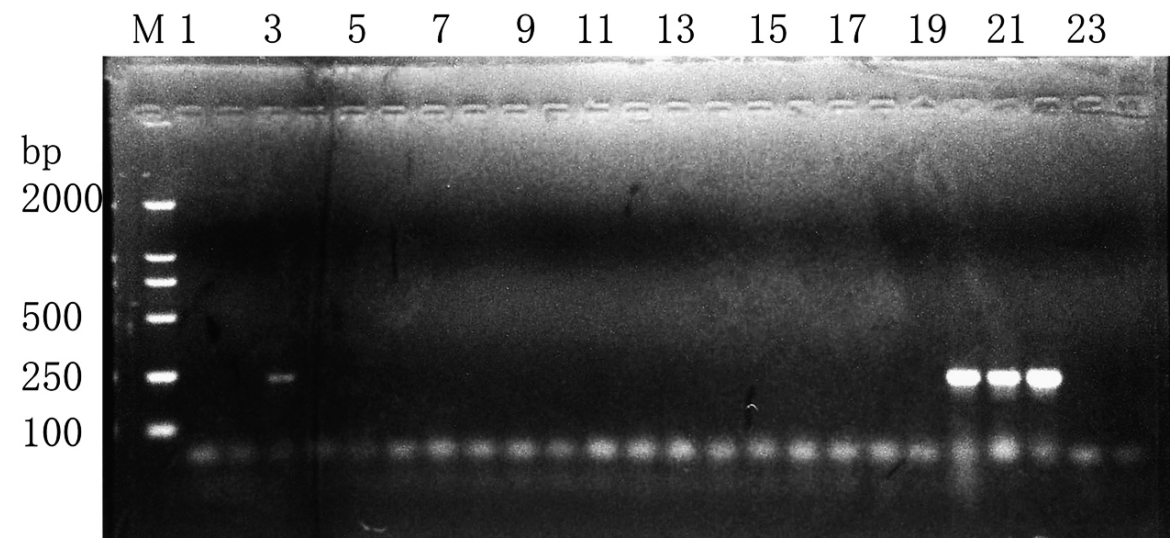

Fig. 3. Detection of WSSV in resting eggs and hatched rotifers by PCR electrophoresis. M: marker; Lanes 1-2: seawater; Lane 3: 3 rotifer resting eggs; Lanes 4-7: other sediment eggs; Lane 8: 2 rotifer resting eggs; Lanes 9-11: other sediment eggs; Lane 12: 1 rotifer resting egg; Lanes 13-15: 1 rotifer each; Lane 16: 3 rotifers; Lanes 17-18: 1 rotifer each; Lane 19: 2 rotifers; Lanes 20-22: positive controls; Lanes 23-24: negative controls 


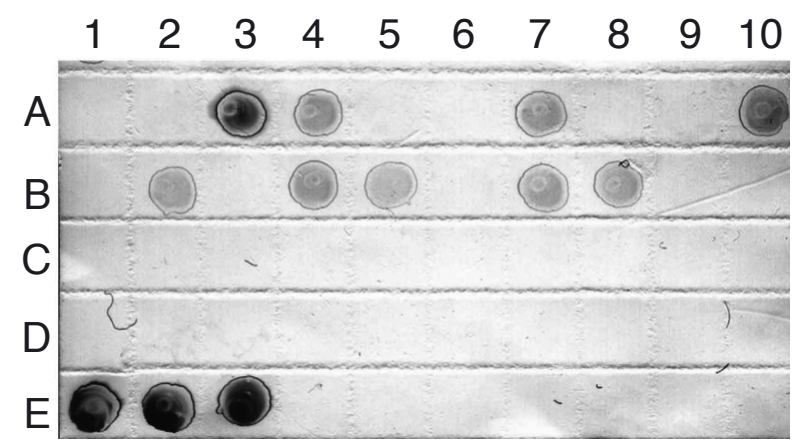

Fig. 4. PCR-dot blot hybridization and direct dot blot hybridization of samples in Fig. 3. A1-B9: PCR-dot blot hybridization of Samples 1-19 from Fig. 3; B10: blank; C1-D9: direct dot blot hybridization of Samples 1-19 in Fig. 3; D10: blank; E1-E3: positive controls; E4: blank; E5-E6: negative controls; E7-E10: blank

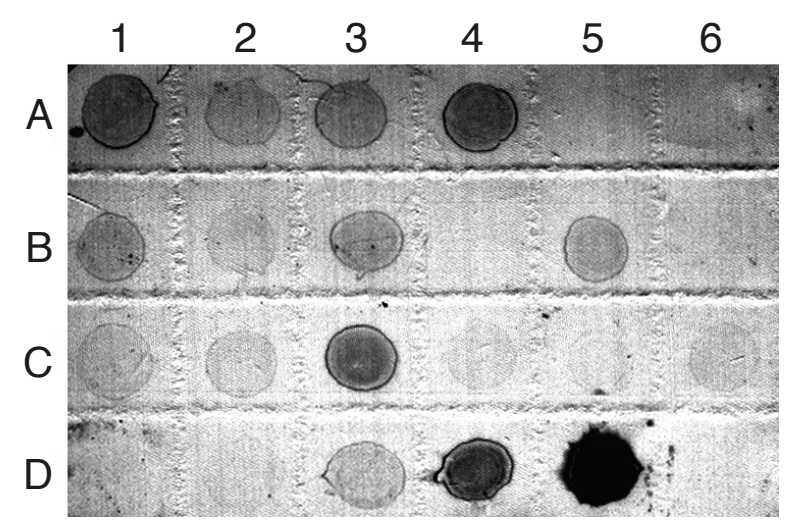

Fig. 5. PCR-dot blot hybridization results for rotifer resting egg samples after Manful King ${ }^{\mathrm{TM}}$ disinfection. A1-A6, B1-B2: 1 rotifer resting egg each; B3: 2 rotifer resting eggs; B4-B5: 3 rotifer resting eggs each; $\mathrm{B} 6$ : seawater; $\mathrm{C} 1-\mathrm{D} 3$ : other egg samples; D4-D5: positive controls; D6 = negative control

at least $72 \%$ in the surveyed population. A total of 4 WSSV-positive rotifer samples out of 7 (including a total of 9 rotifers) suggested $4 / 9=44 \%$ prevalence. Thus, $72 \%$ prevalence in the eggs multiplied by $44 \%$ in the hatched rotifers suggested that approximately $32 \%$ of the rotifers hatching from eggs in the sampled ponds might be WSSV-positive. Because of the testing method, this may be an underestimate. This is a serious possibility that cannot be ignored.

WSSV-positive results from disinfected eggs suggested that WSSV was present within rather than on the surface of the resting eggs. This in turn would indicate that hatched rotifers could become infected with WSSV by vertical transmission. Since rotifer resting eggs over-winter in shrimp pond sediments, such a phenomenon might explain why some shrimp ponds experience WSSV outbreaks in successive years despite implementation of preventative measures. In the last $10 \mathrm{yr}$, shrimp farmers have taken care to breed WSSV-free post-larvae (Jory \& Dixon 1999), to restrict live food inputs (Wang et al. 1998, 1999), to disinfect inlet water (Wang et al. 1998), to fence out crabs (Li \& Dong 2002) and to exclude birds in order to limit horizontal and vertical transmission of WSSV. It is doubtful that currently used treatments with disinfectants such as chlorine or with insecticides would be effective in eliminating zooplankton resting eggs, which have hard thick walls. Thus, it is possible that they could remain in ponds between crops.

Pond preparation usually includes a drying period and sometimes soil liming, but specific attention to resting stages of zooplankton present in pond bottoms between crops has been relatively neglected. This is a preliminary report summarizing PCR detection results only, and it has focused primarily on rotifers. Obviously, further work is needed to determine whether rotifers are true carriers of WSSV and capable of transmitting it to shrimp. In addition, follow up work is needed on other unidentified eggs in the pond sediments that were also WSSV-positive by PCR dot-blot hybridization. This will lead to a better understanding of the risk of WSSV transmission from zooplankton in shrimp pond sediments and the possible development of better prevention methods.

Acknowledgements. The authors thank Juan Shi for providing microalgae for culturing rotifers. This work was funded by the projects under the Major State Basic Research of China (G1999012011), NSFC Project (30371111), China 863 Program (2002AA648010), the 10th National Five Year Major Program (2001BA505B) and the Chinese Ministry of Agriculture Key Laboratory for Sustainable Utilization of Marine Fisheries Resources (2002-2).

\section{LITERATURE CITED}

Cameron A (2002) Survey toolbox for aquatic animal diseases. Australian Centre for International Agricultural Research, Canberra

Chang PS, Chen HC, Wang YC (1998) Detection of white spot syndrome associated baculovirus in experimentally infected wild shrimp, crabs and lobsters by in situ hybridization. Aquaculture 164:233-242

Chou HY, Huang CY, Wang CH, Chiang HC, Lo CF (1995) Pathogenicity of a baculovirus infection causing white spot syndrome in cultured penaeid shrimp in Taiwan. Dis Aquat Org 23:165-173

Huang J, Song XL, Yu J, Yang CH (1995a) Baculoviral hypodermal and hematopoietic necrosis-study on the pathogen and pathology of the shrimp explosive epidemic disease of shrimp. Mar Fish Res 16:1-10 (in Chinese with English abstract)

Huang J, Yu J, Wang XH, Song XL, Ma CS, Zhao FZ, Yang $\mathrm{CH}$ (1995b) Survey on the pathogen and route of transmission of baculoviral hypodermal and hematopoietic necrosis in shrimp by ELISA of monoclonal antibody. Mar 
Fish Res 16:40-50 (in Chinese with English abstract)

Inouye K, Miwa S, Oseko N, Nakano H, Kimura T (1994) Mass mortalities of cultured kuruma shrimp Penaeus japonicus in Japan in 1993: electron microscopic evidence of the causative virus. Fish Pathol 29:149-158

Jory DE, Dixon HM (1999) Shrimp white spot virus in the western hemisphere. Aquac Mag 25:83-91

Li DS, Dong SL (2002) Studies on the pen-closing prevention technique for the WSSV disease of penaeid shrimp-a brief report. Mar Sci 26:67-68 (in Chinese with English abstract)

Lightner DV (1996) A handbook of shrimp pathology and diagnostic procedures for diseases of cultured penaeid shrimp. World Aquaculture Society, Baton Rouge, LA, p 305

Lightner DV (1999) The penaeid shrimp viruses TSV, IHHNV, WSSV and YHV: current status in the Americas, available diagnostic methods and management strategies. J Appl Aquacult 9:27-52

Lo CF, Leu JH, Ho CH, Chen CH and 8 others (1996a) Detection of baculovirus associated with white spot syndrome (WSBV) in penaeid shrimps using polymerase chain reaction. Dis Aquat Org 25:133-141

Lo CF, Ho CH, Peng SE, Chen CH and 7 others (1996b) White spot syndrome baculovirus (WSBV) detected in cultured and captured shrimp, crabs and other arthropods. Dis Aquat Org 27:215-225

Marcus NH (1989) Abundance in bottom sediments and hatching requirements of eggs of Centropages hamatus (Copepoda: Calanoida) from the Alligator Harbor region, Florida. Biol Bull (Woods Hole) 176:142-146

Nakano H, Koube H, Umezawa S, Momoyama K, Hiraoka M, Inouye K, Oseko N (1994) Mass mortalities of cultured kuruma shrimp, Penaeus japonicus, in Japan in 1993: epizootiological survey and infection trials. Fish Pathol 29: 135-139

Rajendran KV, Vijayan KK, Santiago TC, Krol RM (1999) Experimental host range and histopathology of white spot

Editorial responsibility: Timothy Flegel,

Bangkok, Thailand sydrome virus (WSSV) infection in shrimp, prawns, crabs and lobsters from India. J Fish Dis 22:183-191

Takahashi Y, Itami M, Kondo M, Maeda M, Fujii R, Tomonaga S, Supamattaya K, Boonyaratpalin S (1994) Electron microscopic evidence of bacilliform virus infection in Kuruma shrimp (Penaeus japonicus). Fish Pathol 29: 121-125

Wang $\mathrm{CH}$, Lo CF, Leu JH, Chou CM and 6 others (1995) Purification and genomic analysis of baculovirus associated with white spot syndrome (WSBV) of Penaeus monondon. Dis Aquat Org 23:239-242

Wang K, Shi CY, Huang J (2000) The comparision of different methods of DNA extracting applied in PCR detection of hypodermal and hematopoietic necrosis baculovirus. Mar Fish Res 21:8-12 (in Chinese with English abstract)

Wang YG, Shariff M, Sudha PM, Srinivasa Rao PS, Hassan MD, Tan LT (1998) Managing white spot disease in shrimp. INFOFISH Int 3:30-36

Wang YG, Tan OL, Lee KL, Hassan MD, Shariff M (1999) Health management of shrimp during grow-out. INFOFISH Int 4:30-36

Wongteerasupaya C, Vickers JE, Sriurairatana S, Nash GL and 6 others (1995) A non-occluded, systemic baculovirus that occurs in cells of ectodermal and mesodermal origin and causes high mortality in the black tiger prawn Penaeus monondon. Dis Aquat Org 21:69-77

Yan DC, Dong SL, Huang J, Yang B (2004) Trace white spot syndrome virus (WSSV) detection with polymerase chain reation (PCR)-dot blot hybridization. High Technol Lett 14:33-36 (in Chinese with English abstract)

Yang B, Huang J, Song XL, Shi CY, Wang XH (2001) Comparison of seven kinds of disinfectants against (WSSV) DNA. Mar Fish Res 22:6-8 (in Chinese with English abstract)

Yang F, He J, Lin XH, Li Q, Deng P, Zhang XB, Xu X (2001) Complete genome sequence of the shrimp white spot bacilliform virus. J Virol 75:11811-11820

Submitted: June 11, 2003; Accepted: December 9, 2003

Proofs received from author(s): April 5, 2004 